УДК 330.115

JEL classification: $C 31, \mathrm{L1}$

Жуковська О. А. канд. фіз.-мат. наук, доиент ORCID ID: 0000-0003-1110-9696

Скляр П. А. ORCID ID: 0000-0002-8956-4130

Національний технічний університет України «Київський політехнічний інститут імені Ігоря Сікорського»

\title{
МОДЕЛЮВАННЯ ОБСЯГУ ПРОДУКЦІЇ ДЛЯ ЗАДОВОЛЕННЯ ПОПИТУ ЗА ДОПОМОГОЮ ДИНАМІЧНОЇ МОДЕЛІ ЧАСТКИ РИНКУ ТА ІНТЕРВАЛЬНОЇ МОДЕЛІ РОЗМІРУ РИНКУ
}

\author{
MODELLING OF COMPANY PRODUCTION VOLUMECOMPANY FOR \\ DEMAND SATISFACTION WITH DYNAMIC MODEL OF MARKET SHARE AND \\ INTERVAL MARKET SIZE MODEL
}

\begin{abstract}
У статті розглянута математична модель аналізу і прогнозування ринкової частки підприємства, модель інтервальної оиінки розміру ринку та обсягу продукиї, який би задовольняв існуючий та прогнозний попит з урахуванням функиії корисності продукту та виду конкурентної взаємодії. У роботі проаналізована модель залежностідинаміки частки ринку від зміни із часом корисності продукту підприємствата продуктів ї̈ головних конкурентів. Для визначення обсягу продукиії підприємстварозглянута імовірнісна модель визначення розміру ринку та здійснений перехід до інтервальної моделі, яка дозволяє врахувати коливальний характер иін.Показано, щуо розглянута модель дозволяє дослідити динаміку розвитку та проаналізувати стратегії поведінки підприємствана ринку. Крім иьього,доведено на історичних даних, щзо модель дає достатньо точні результати та прийнятне відхилення. У результаті на основі запропонованої моделі визначені межі, у яких буде коливатися розмір ринку тапроаналізована динаміка розвитку підприємства та його конкурентів. Важслио зазначити, щзорозглянуті дані враховують можливі коливання ціни у визначеному інтервалі, а також можливу зміну конкурентних позиції на ринку. На основі даних динаміки частки ринку та загального розміру ринку побудований інтервал для визначення обсягу продукиії, який би задовольняв попит на товар компаній. Визначний прогнозний обсяг продукиї, який потрібно поставляти на ринок кожне із підприємств для задоволення попиту. Для розглянутого сценарію були сформовані припущення щодоподальшої стратегї поведінки компанії для збереження, а також посилення своїх конкурентних позицій на ринку. Отже, у роботі показано, як на основі динамічної моделі частки ринку та моделі інтервального розрахунку розміру ринку з урахуванням коливального характеру иін та можливої зміни конкурентних позиції,підприємство може визначити напрям своєї товарної та маркетингової політики, оперуючи функцією корисності продукту, часткою ринку та інтервальною оцінкою розміру ринку.
\end{abstract}

Ключові слова: ринкова частка, конкурентна взаємодія, модель Лотки-Вольтерра, прогнозування розвитку ринку, інтервальна модель розміру ринку.

The mathematical model for analysis and forecasting company market share, the interval model for market size and company product volume estimation in view of the product utility function and the type of competitive interaction is described in the research paper. The model of the dependence of the market share dynamics on the company product utility change with time and the products of its main competitors determination of company product value, probability market size model is examined and transferred to interval model which allows to consider oscillatory nature of 
prices. It is shown that the proposed model allows to study and to analyse the dynamic of development and various strategies of the companies' behaviour in the market. Analysis and modelling on historical data prove that the model gives sufficiently accurate results and an acceptable deviation. As a result, on the basis of the proposed model, the boundaries in which the size of the market will fluctuate were determined, and the company development dynamics are analysed in accordance with competitors' development. It is important to note that the data considered take into account possible price fluctuations in a certain interval, as well as possible change in the competitive positions in the market. Based on the market share dynamics and the total market size, an interval was established for determining the volume of products that would satisfy the demand for the goods of all companies. An outstanding forecast volume of products that each enterprise must supply to the market to meet demand. For the scenario under consideration, an assumptions were made about a further strategy for the company's behaviour to preserve, as well as strengthen its competitive positions in the market. Thus, the work shows how, based on the dynamic model of the market share and the interval model of market size, which takes into account the fluctuating nature of prices and the possible change in the competitive position, the company can determine the direction of the commodity and marketing policy, using the utility function of the product, market share and interval estimation of market size.

Keywords: market share, competitive interaction, Lotka-Volterra model, market forecasting, interval model of market size.

Вступ. У сучасних ринкових умовах основним завданням вітчизняних підприємств є збереження та посилення своїх конкурентних позицій. Для досягнення цієї мети компанії необхідно визначити своє положення на ринку, залежно від якого будувати свою подальшу стратегію, зокрема, визначення об'єму продукції для можливого подальшого збуту.Існують різні методи аналізу та дослідження положення компанії на ринку, у тому числіметоди аналізу конкурентних переваг (SWOT, GAP, LOTS, PIMS, "Мак-Кінзі") [1]. Зазначені моделі дозволяють робити висновок про подальший розвиток компанії, однак, такі моделі носять якіснийхарактер і не надають аналітичний аналіз ринку і стратегічного положення компанії.Моделювання динаміки ринкової конкуренції вперше зустрічаємо в роботах Лотки (1925) [2] і Вольтерра (1926) [3],надалі їх ідеї отримали розвиток і практичне застосування, зокрема в роботах [4-8]. Проте, у цих підходах аналіз динаміки ринку ототожнюється заналізом динаміки частки ринку конкуруючих за ринковий потенціал компаній, не враховуючи інші економічні фактори, зокрема, такі важливі як абсолютний попит на ринку та можливу нестабільність ціни. Водночас існують моделі, які враховують вище зазначені показники, однак залишають без уваги динамічний характер конкурентної взаємодії $[9,10]$. Описані вище факти не дозволяють визначити необхідний для поглинання ринком об’єм продукції повністю та без надлишку.

Тому постає задача побудови ефективного механізму для кількісної оцінки та прогнозу випуску необхідного об'єму продукції для задоволення існуючого попиту на ринку з урахуванням можливої зміни положення компанії відносно їі конкурентів.

Постановка завдання. Метою даноїстатті єформуваннястратегії поведінки компаніїдля збереження або посилення своїх конкурентних позицій на основідинамічноїмоделічастки ринку та моделі інтервального розрахунку розміру ринку. 
Методологія. У процесі дослідження використано методи визначення ємності ринку, динаміки частки ринку, модель інтервальної оцінки розміру ринку для побудови моделі для прогнозування ефективного випуску продукції 3 метою задоволення ринкового попиту та формування стратегії поведінки.

Результати дослідження. Формуваннястратегії поведінки компанії для збереження або посилення своїх конкурентних позицій певною мірою залежить від визначення об'єму продукції, яку може поглинути ринок.

Такий об'єм продукції може бути визначений:

$$
V_{i}(t)=x_{i}(t) C,
$$

де $V_{i}(t)$ - об'єм продукції компанії $i$, який задовольнить попит на ринку, $C$ розмір ринку, а $x_{i}(t)$ - частка ринку виражена як залежність від функції корисності, що дозволяє врахувати динамічний характер конкурентного середовища:

$$
x_{i}(t)=\frac{\exp \left(f_{i}(t)\right)}{1+\sum_{j=1}^{N} \exp \left(f_{j}(t)\right)}, \quad i=1, \ldots, N-1
$$

де $f_{i}(t)$ - функція корисності продукту $i$-ої фірми.

3 рівняння (2) випливає, що на частку ринку кожної фірми впливає не тільки власна функція корисності, а ще й функції корисності інших фірмконкурентів. Зокрема, частка ринку фірми $i$ буде зростати, коли власна функція корисності $f_{i}(t)$ зростає і знижуватися, коли функція корисності $f_{j}(t)$ будьякого конкурента зростає.

Для визначення розміру ринку зазвичай використовується імовірнісна модель:

$$
C=\sum_{i=1}^{n} \sum_{j=1}^{m} w_{i} p_{i j} k_{j},
$$

де $w_{i}$ - ціна $i$-го товару, $p_{i j}$ - імовірність того, що $i$-й товар буде користуватися попитом у ј-му сегменті, при цьому $\sum_{i=1}^{n} \sum_{j=1}^{m} p_{i j}=1, k_{j}-$ кількість підприємств у $j$ му сегменті, що споживають $i$-й товар.

Проте, модель (3) не враховує об'єм придбання товару, тому модифікуємо iï таким чином:

$$
C=\sum_{i=1}^{n} \sum_{j=1}^{m} w_{i} p_{i j} q_{i} k_{j}
$$

де $q_{i}$ - середня кількість замовлення $i$-го товару.

Однак, на практиці розрахувати імовірнісні характеристики неможливо, тому використовують показник частоти придбання $i$-го товару в $j$-му сегменті: 


$$
p_{i j}^{*}=\frac{g_{i j}}{b_{j}}, i=\overline{1, n}, \quad j=\overline{1, m}
$$

де $b_{j}$ - загальна кількість досліджуваних підприємств у j-му сегменті, $g_{i j}-$ кількість підприємств, які згодні купувати $i$-й товар у j-му сегменті.

Однак, згідно з теорією ймовірностей, заміна невідомих імовірнісних характеристик частотою правомірна лише при достатньо великому обсязі досліджуваних підприємств. Але процес опитування великої кількості підприємств $є$ досить трудомістким і довготривалим процесом. Також на практиці неможливо точно визначити ціну, за якою буде продаватися товар. Тому за аналогією з[9] запишемо інтервальну модель розміру ринку:

$$
\mathbf{C}=\sum_{i=1}^{n} \sum_{j=1}^{m} \mathbf{W}_{i} \mathbf{I}_{i j} q_{i} k_{j}
$$

де $\mathbf{W}_{i}=\left[w_{i}^{-}, w_{i}^{+}\right]-$інтервал, у межах якого може коливатися ціна $w_{i} i$-го товару, $w_{i}^{-}, w_{i}^{+}-$нижня та верхня границі інтервалу $W_{i}$ відповідно, $I_{i j}-$ довірчий інтервал:

$$
I_{i j}=\left[\frac{p_{i j}^{*}+\frac{t_{\beta}^{2}}{2 b_{j}}-t_{\beta} \sqrt{\frac{p_{i j}^{*}\left(1-p_{i j}^{*}\right)}{b_{j}}+\frac{t_{\beta}^{2}}{4 b_{j}^{2}}}}{1+\frac{t_{\beta}^{2}}{b_{j}}}, \frac{p_{i j}^{*}+\frac{t_{\beta}^{2}}{2 b_{j}}+t_{\beta} \sqrt{\frac{p_{i j}^{*}\left(1-p_{i j}^{*}\right)}{b_{j}}+\frac{t_{\beta}^{2}}{4 b_{j}^{2}}}}{1+\frac{t_{\beta}^{2}}{b_{j}}}\right]
$$

де $\beta$ - довірча імовірність, яка накриває невідоме значення імовірнісної характеристики $p_{i j}, t_{\beta}=\arg F\left(\frac{1+\beta}{2}\right)-$ функція, обернена гауссівській функції розподілу $F\left(\frac{1+\beta}{2}\right)$.

Таким чином, з урахуванням вище сказаного модель (1) набуває вигляду

$$
\mathbf{V}_{i}(t)=x_{i}(t) \mathbf{C}
$$

Визначимо стратегію компаній, які оперують на ринку засобів захисту рослин, залежно від очікуваної зміни конкурентних позицій, спираючись на модель (8). Надмірний об’єм продукції може призвести до падіння економічних показників компанії і, як наслідок, частки ринку. Така ж ситуація буде спостерігатися при недооцінюванні можливих продажів.

Розглянемо особливості ринку засобів захисту рослин.По-перше, у більшості країн (включаючи Україну) декілька великих компанії домінують на всьому ринку. По-друге, характеристики продуктів є досить незмінними протя- 
гом часу (для випуску нового продукту необхідно не менше 10 років), відповідно ринок може вважатися сталим для прогнозного періоду. Візьмемо частки ринку трьох головних компаній (для збереження комерційної таємниці умовно назвемо їх компаніями 1, 2 і 3 відповідно, де компанія 1 - наша компанія, компанії 2 і 3 - конкуренти) за період 9,5 років (інформація про ринкові частки доступна поквартально).

Дослідження показали, що клієнтами компаній 1, 2, 3 є великі агрохолдинги, земельний капітал яких становить більше 50000 га (позначимо як 1-ий сегмент ринку), та середні сільськогосподарські підприємства, що володіють ділянками розміром від 5000 га (2-ий сегмент). Розмір замовлення у 1-ому сегменті значно більший за розмір замовлення у 2-ому сегменті, тому такий поділ $\epsilon$ доречним. Дослідження показали, що до 1-го сегменту можна віднести 34 агрохолдинги, а до 2-го - 609 сільськогосподарських підприємств.

Визначимо очікуваний розмір ринку за допомогою інтервальної моделі

У 1-му сегменті ринку з досліджуваних 34 компаній виявилося, що $g=33$ господарства будуть купувати препарати компаній 1,2 або 3. Таким чином за (5) частота придбання товару становить $p_{1}^{*}=0,97$.Будуємо довірчий інтервал за формулою (7):

$$
I_{1}=\left[i_{1}^{-}, i_{1}^{+}\right]=[0,812 ; 0,996]
$$

при довірчій імовірності $\beta=0,99$.

Ціна на товар може коливатись від 14 до 16 у.о., тобто

$$
W=\left[w^{-}, w^{+}\right]=[14 ; 16] .
$$

Обсяг замовлення вимірюється в літрах, $\mathrm{i}$ для сегменту 1 середнє значення складає 395 тис. літрів.

Як було зазначено раніше, 2-ий сегмент ринку складається з 604 підприємств. Процес опитування усіх підприємств є досить трудомістким завданням, тому обираємо випадковим чином $b=80$ господарств. Опитування показало, що 76 підприємства будуть купувати продукціюкомпаній 1, 2 або 3. Частота придбання становить $p_{2}^{*}=0,95$ та довірчий інтервал буде таким:

$$
I_{2}=\left[i_{2}^{-}, i_{2}^{+}\right]=[0,857 ; 0,984]
$$

при довірчій імовірності $\beta=0,99$.

Припустимо, що цінова дискримінація на ринку відсутня, тобто ціна для 2-го сегменту може коливатися у тих самих межах $W=\left[w^{-}, w^{+}\right]=[14 ; 16]$.A cepeдній обсяг замовлення у цьому сегменті складає 52 тис. літрів.

3 наведених вище даних можемо розрахувати загальний розмір ринку за (6)(в тис. у.о.): 


$$
\mathbf{C}=\sum_{j=1}^{2}\left[c_{j}^{-}, c_{j}^{+}\right]=[532710 ; 712425] .
$$

Розглянута вище модельчастки ринку (5) буде застосована для оцінки ринкових частки компанії, яка оперує на ринку засобів захисту рослин, та її основних конкурентів. Також ми побудуємо прогнозний сценарій розвитку для нашої компанії, та розрахуємо, який об'єм випуску повинен бути, щоб задовільнити відповідний попит на ринку, використовуючи модель (8).

Функціональну форму функції корисності $f_{i}(t)$ для імітації конкуренції між фірмами на визначеному ринку обираємо згідно з роботою [8]:

$$
f_{i}(t)=\ln \left(x_{i}(t)\right)-\ln \left(x_{0}(t)\right), i=\overline{1, N} .
$$

3 рівняння (9) випливає, що найбільша компанія встановлює ціни на ринку, тоді як невелика компанія приймає, «наслідує» ціни, які $\epsilon$ на ринку. Вважається, що фірма наслідує ціну при неможливості істотно вплинути на ринкову ціну, змінюючи швидкість свого виробництва або цінової стратегії. Навпаки, поведінка компаній, які встановлюють ціни, впливає на функціонування ринку.

Для оцінки відповідності результатів за моделлю частки ринку дійсності, зробимо перевірку на історичних даних і знайдемо показники, які відображають ефективність прогнозу: середньоквадратична похибка (MSE), середня абсолютна похибка (MAPE) та стандартне відхилення (FS). Ці показники можуть бути розраховані таким чином:

$$
M S E=\frac{1}{n} \sum_{i=1}^{n}\left(h_{i}-p_{i}\right)^{2}, M A P E=\frac{1}{n} \sum_{i=1}^{n}\left|\frac{h_{i}-p_{i}}{h_{i}}\right| 100 \%, F S=2 \frac{S_{h}-S_{p}}{S_{h}+S_{p}},
$$

де $h_{i}$ та $p_{i}$ - відповідне історичне значення та значення, отримане за допомогою моделі, $S_{h}$ та $S_{p}$-відповідні стандартні відхилення.

Використовуючи (9) отримаємо набір дискретних значень функції корисності $f_{i}(t), i=1,2,3$, для даного періоду (дев'ять 3 половиною років, інформація доступна поквартально, таким чином ми отримаємо 38 точок), за якими отримаємо:

$$
\begin{aligned}
& f_{1}(t) \approx-0,0005 t^{2}+0,0451 t+1,0653 \\
& f_{2}(t) \approx 0,0012 t^{2}-0,0227 t+1,2666 \\
& f_{3}(t) \approx 0,0043 t^{2}-0,1677 t+2,0282
\end{aligned}
$$

для компаній 1, 2 і 3 відповідно (рис. 1). 


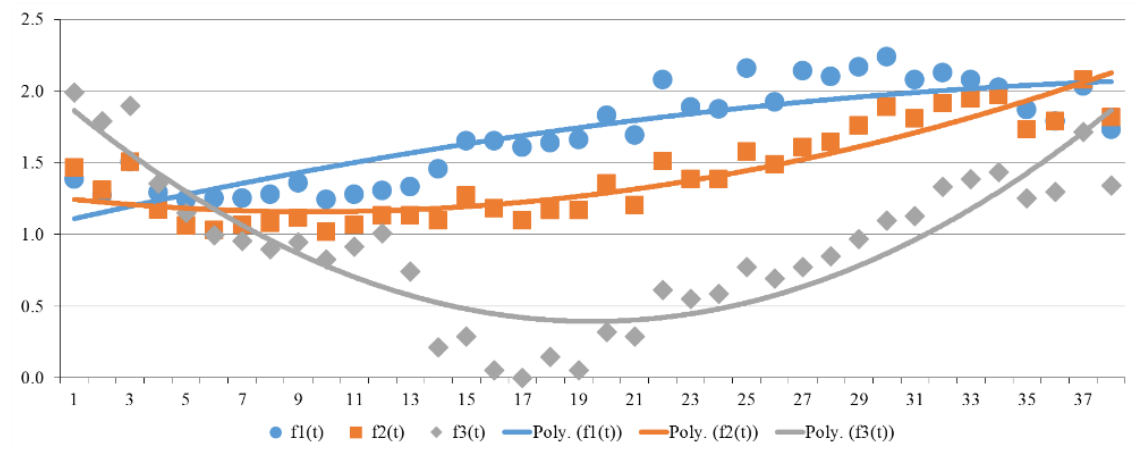

Рисунок 1 - Функції корисності $f_{1}(t), f_{2}(t), f_{3}(t)$ за даний період

Підставляючи (10) - (12) у рівняння (2) отримаємо частки ринку $x_{1}(t)$, $x_{2}(t)$ та $x_{3}(t)$ для компаній 1,2 і 3 відповідно, які наведені на рис. 2 у порівнянні з реальними даними. В табл. 1 наведені прогнозовані значення частки ринку компаній 1, 2 і 3 (на рис. 2 позначено пунктиром).

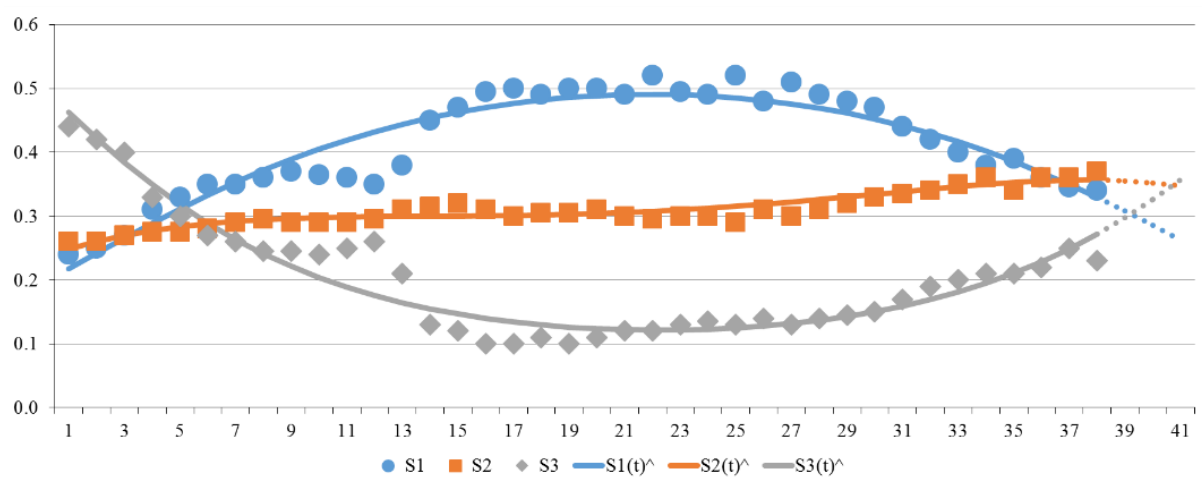

Рисунок 2 - Частки ринку $x_{1}(t), x_{2}(t), x_{3}(t)$ за даний та прогнозний періоди

Таблиця 1 - Прогнозні значення часток ринку

\begin{tabular}{|c|c|c|c|}
\hline $\mathrm{t}$ & $x_{1}(t)$ & $x_{2}(t)$ & $x_{3}(t)$ \\
\hline 39 & 0.308 & 0.355 & 0.297 \\
\hline 40 & 0.286 & 0.352 & 0.326 \\
\hline 41 & 0.263 & 0.347 & 0.357 \\
\hline 42 & 0.239 & 0.340 & 0.391 \\
\hline
\end{tabular}

Показники середньоквадратичної похибки (MSE), середньої абсолютної похибки (MAPE) та стандартного відхилення $(F S)$, що наведені в табл. 2 свідчать про досить точний рівень прогнозу та невелике відхилення від реальних значень. 
Таблиця 2 - Показники достовірності моделі (2)

\begin{tabular}{|c|c|c|c|}
\hline Показник & Компанія 1 & Компанія 2 & Компанія 3 \\
\hline$M S E$ & 0.0007 & 0.0001 & 0.0007 \\
\hline$M A P E$ & $4.7 \%$ & $2.6 \%$ & $10.5 \%$ \\
\hline$F S$ & 0.0575 & 0.0432 & 0.0099 \\
\hline
\end{tabular}

3 рисунку 2 видно, що компанія 1 довгий час була лідером ринку, але останні роки втрачає свої позиції на користь компаній 2 і 3. Компанія 2 стає лідером ринку 3 невеликим відривом від компанії 1. Позитивна динаміка росту спостерігається у компанії 3 , яка продовжується і у прогнозних значеннях на наступний рік. Цей імпульс дозволить компанії 3 вирватися в лідери ринку, тоді як частка ринку компанії 1 продовжить спадати, а частка компанії 2 буде коливатися без значних змін. 3 цього випливає, що компаніям 1 і 2 слід замислитися над покращенням своєї функції корисності. Це може бути або зменшення ціни, або значне покращення характеристик власного товару, або ж направлена маркетингова акція.

Беручи до уваги розрахований об'єм ринку та частки ринку трьох підприємств, можемо представити кількість продукції, який повинна поставляти на ринок кожна з компаній, щоб задовільнити попит (таблиця 3).

Таблиця 3- Прогнозні значення об’ємів продукції кожної з компаній

\begin{tabular}{|c|c|c|c|c|c|c|}
\hline $\mathrm{t}$ & \multicolumn{2}{|c|}{$V_{1}(t)$} & \multicolumn{2}{c|}{$V_{2}(t)$} & \multicolumn{2}{c|}{$V_{3}(t)$} \\
\hline & $\begin{array}{c}\text { нижня } \\
\text { границя }\end{array}$ & $\begin{array}{c}\text { верхня гра- } \\
\text { ниця }\end{array}$ & $\begin{array}{c}\text { нижня гра- } \\
\text { ниця }\end{array}$ & $\begin{array}{c}\text { верхня } \\
\text { границя }\end{array}$ & $\begin{array}{c}\text { нижня } \\
\text { границя }\end{array}$ & $\begin{array}{c}\text { верхня } \\
\text { границя }\end{array}$ \\
\hline 39 & 164133 & 219504 & 189327 & 253198 & 158408 & 211849 \\
\hline 40 & 152249 & 203611 & 187695 & 251015 & 173541 & 232087 \\
\hline 41 & 139930 & 187137 & 184998 & 247408 & 190194 & 254357 \\
\hline 42 & 127313 & 170263 & 181118 & 242219 & 208335 & 278618 \\
\hline
\end{tabular}

Висновки. На основі моделі оцінки ринкової діяльності компанії за допомогою визначення інтервального обсягу ринку, частки ринку, та випуску продукціїпроаналізовано динаміку розвитку компаній, визначені межі, у яких буде коливатися розмір ринку, та надані прогнозні значення об'ємів продукції для кожної з компаній. Розглянута модель об'єму ринку є імовірнісною, а також дозволяє врахувати коливання ціни на ринку. Модель частки ринку була перевірена на історичних даних: спостерігається невелике відхилення від фактичних результатів. Модель враховує конкурентну взаємодію з використанням функцій корисності продукту компаній. На основі даних динаміки частки ринку та загального розміру ринку побудований інтервал для визначення обсягу продукції, який би задовольняв попит на товар компаній.

Розглянута модель дозволяє проаналізувати конкурентну взаємодію на ринку, визначити напрям продуктової абомаркетингової стратегії компанії, оцінити розмір ринку враховуючи коливальний характер цін, а також побудувати інтервал потрібного на ринку обсягу продукції. 


\section{Література:}

1. Мак-Дональд М. Стратегическоепланированиемаркетинга [Текст] /М. Мак-Дональд. СПб. : Питер, 2000. - 320 с.

2. Lotka A. ElementsofPhysicalBiology / A.J. Lotka. - Baltimore: WilliamsandWilkins, 1925 $-460 \mathrm{c}$.

3. Вольтерра В. Математическаятеорияборьбы за существование / В. Вольтерра ; пер. с фр. под ред. Ю. М. Свирежева. - М. : Наука, 1976. - 286 с.

4. Baumol W.J. Contestablemarkets: Anuprisinginthetheoryofindustrystructure / W.J. Baumol // AmericanEconomicReview. - 1982. - №72. - C. 1-15.

5. Modis T. Insightsoncompetitionfrom a science-basedanalysis / T. Modis // Advan?esinPsychologyResearch. - 2011. - №88. - C. 1-25.

6. Chiang S. AnapplicationofLotka-VolterramodeltoTaiwan'stransitionfrom $200 \mathrm{~mm}$ to 300 mmsiliconwafers / Su-YunChiang // TechnologicalForecastingandSocialChange. - 2012. №79. - С. 383-392.

7. Базыкин А. Д. Нелинейнаядинамикавзаимодействующихпопуляций / А. Д. Базыкин. Москва-Ижевск: Институткомпьютерныхисследований, 2003. - 368 с.

8. Marasco A. MarketsharedynamicsusingLotka-Volterramodels / A. Marasco, A. Picucci, A. Romano // TechnologicalForecasting\&SocialChange. - 2016. - №105. - C. 49-62.

9. Жуковская О. А. Формальная модель оценки ёмкости рынка в условиях интервальной неопределенности / О.А. Жуковская // Журнал «Управляющие системы и машины». 2008. - № 5.- С. 88-92.

10. Жуковська О. А. Економіко-математичне моделювання ємності ринку та ринкової частки компанії / О. А. Жуковська, П. А. Нікітіна // Економічний вісник. - 2016. - №13. - C. 546-550. 